\title{
SUSTENTABILIDADE, ORGANIZAÇÕES E SOCIEDADE
}

No momento em que todos aguardam a $\mathrm{RIO}+20$, há trabalhos em várias áreas do conhecimento que lidam com os desafios em conciliar os princípios do desenvolvimento sustentável com as práticas de gestão das organizações. Sustentabilidade é um tema de crescente interesse, mas, ao mesmo tempo, seu entendimento e operacionalização implicam grande complexidade prática e teórica, envolvendo dilemas, paradoxos e contradições. As indicações bibliográficas abaixo reúnem um conjunto de leituras para os que querem entender as dificuldades e o potencial de mudança no cotidiano das organizações, já que é a tradução particular que cada organização e cada gestor faz do seu cenário que materializa essa ideia-força chamada sustentabilidade. As obras foram selecionadas pelas professoras Andrea Leite Rodrigues e Sylmara Lopes F. Gonçalves Dias, ambas da Escola de Artes, Ciências e Humanidades (EACH-USP).

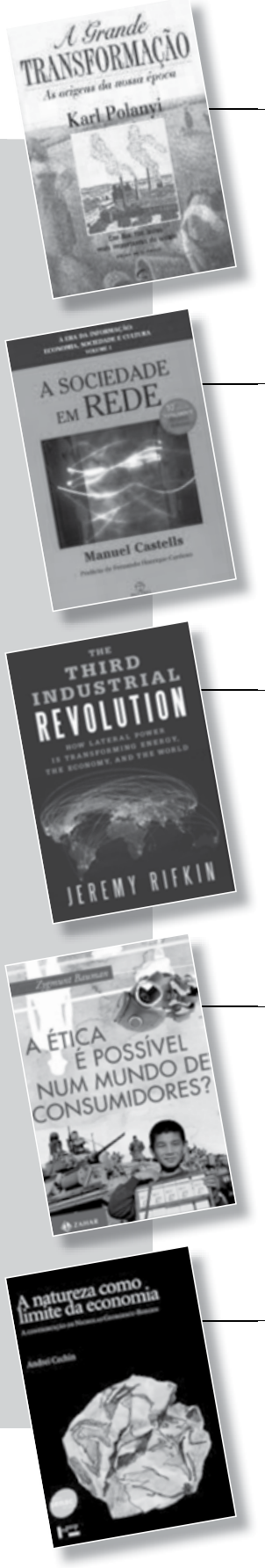

A GRANDE TRANSFORMAÇÃO: As origens da nossa época. Karl Polanyi. São Paulo: Campus, 2000 (1. ed. 1944). 354 p. Um clássico, essencial para entender as origens históricas dos dilemas entre econômico e social. 0 autor reúne evidências na história para mostrar que a atividade econômica sempre esteve imersa em outras atividades da vida em sociedade; a primazia do econômico (e do mercado) são fenômenos do século XX, após a crise do liberalismo. Destaque para a forma como o autor apresenta o fascismo e o socialismo como modos de organização que também propuseram dar primazia ao social, mas à custa de regimes de exceção e horror.

A SOCIEDADE EM REDE. Manuel Castells. 7. ed. São Paulo: Paz e Terra, 2003. 698 p. 0 sociólogo espanhol é um dos precursores do estudo sobre o impacto da tecnologia na sociedade. Publicado em 1996, este é o primeiro volume da trilogia composta por 0 poder da identidade (1997) e 0 fim do milênio (1998). Sua obra é essencial, uma vez que pensar uma nova relação entre social e econômico requer outra organização do trabalho, bem como um novo modo de produção e de distribuição do conhecimento.

THE THIRD INDUSTRIAL REVOLUTION: How lateral power transforming energy, the economy, and the world. Jeremy Rifkin. New York: Palgrave Macmillan, 2011. 304 p. Rifkin explora como a tecnologia da internet e as energias renováveis estão se fundindo para criar uma poderosa "terceira revolução industrial", que começa com casas, escritórios ou fábricas produzindo sua própria energia e compartilhando-a numa "internet da energia". Segundo o autor, parte crescente da prosperidade do século XXI virá de uma nova organização social assinalada pela descentralização, cooperação e partilha. A gestão organizacional passará, necessariamente, por mudanças drásticas.

A ÉTICA É POSSÍVEL NUM MUNDO DE CONSUMIDORES? Zygmunt Bauman. São Paulo: Zahar, 2011.280 p. A coerção política e social do passado tem sido cada vez mais substituída pela sedução ou persuasão. Entretanto, em vez de procurar soluções para os problemas insolúveis do mundo moderno, Bauman propõe reformular a maneira como pensamos sobre essas dificuldades, saindo da perspectiva individualista, privada e competitiva para a busca de soluções coletivas e cooperativas. Consequentemente, a ética, entendida como a aceitação de nossas responsabilidades em relação ao bem-estar geral, é crucial.

A NATUREZA COMO LIMITE DA ECONOMIA: A contribuição de Nicholas Georgescu-Roegen. Andrei Cechin. São Paulo: Senac, São Paulo/Edusp, 2010, 264 p. 0 autor aborda a inter-relação entre economia e natureza resgatando a perspectiva das limitações biofísicas ao crescimento da economia lançada por Georgescu-Roegen. Discute o quanto o futuro energético da humanidade está no centro da problemática do chamado desenvolvimento sustentável, ao mesmo tempo que alerta para o fato de que o processo de produção econômica vem necessariamente acompanhado da geração de resíduo e poluição. Vê com ceticismo a ideia consagrada de crescimento econômico ilimitado. 